\title{
Effect of Escherichia coli enterotoxins on macromolecular absorption
}

\author{
M Verma, S Majumdar, N K Ganguly, B N S Walia
}

\begin{abstract}
Macromolecular absorption of gliadin, a wheat protein and $\alpha$ lactalbumin, a milk protein was evaluated in control and Echerichia coli enterotoxin (heat-stable, heat-labile, and both heat-stable and heatlabile enterotoxin) treated mice. The peak concentration of gliadin and lactalbumin was two hours and three hours after their ingestion, respectively. There was also a significant increase $(p<0.01)$ in the absorption of both the proteins in all the three toxin treated groups compared with the control group. These results suggest that intestinal permeability and macromolecular absorption changes after $E$ coli infection.
\end{abstract}

(Gut 1994; 35: 1613-1616)

The possible influence of infectious diarrhoea on subsequent food sensitisation in infants is still under investigation. Different animal models of gastrointestinal infection have shown that some types of infection (for example, rotavirus, enteroaggregative Escherichia coli strain RDEC-1) might increase intestinal permeability to antigens, ${ }^{1-3}$ but others might not (for example, cholera toxin induced secretory diarrhoea). ${ }^{4}$ The intestinal endocytosis of antigenic food proteins is a physiological process, which generally does not lead to pathological immune responses. ${ }^{5}$

In our work, we studied the effect of diarrhoea caused by enterotoxigenic $E$ coli (ETEC) on antigen absorption in weanling mice. ETEC strains are important causes of gastrointestinal diseases and especially affect infants throughout the world. ${ }^{67}$ It produces two types of toxins heat-labile (LT) enterotoxin and heat-stable (ST) enterotoxin. ${ }^{8} 9$ The first is the activator of adenylate cyclase resulting in an increase in cAMP while the second is the activator of guanylate cyclase resulting in an increase in cGMP. ${ }^{1011}$ The increased cyclic nucleotide concentration leads to various physiological changes including alteration in the intestinal transport of electrolytes and nutrients. ${ }^{12}$

Our aim in this study was to find out if ETEC enterotoxins affects small intestinal barrier function, which may further affect macromolecular permeability. This was assessed by measuring concentration of gliadin and $\alpha$ lactalbumin in serum after an oral gliadin and lactalbumin administration as an indication of intestinal macromolecular permeability. ETEC infection in a suckling mouse model provides an excellent system in which to examine this mechanism because of its similarity to disease in human infants.

\section{Methods}

\section{TOXIN TREATMENT}

Albino mice (2-3 weeks old) were used in the study. Standard ST enterotoxin producing $E$ coli strain $\mathrm{T}_{52}$, both $\mathrm{ST}$ and $\mathrm{LT}$ enterotoxin producing $E$ coli strain $\mathrm{T}_{83}$, and LT enterotoxin producing $E$ coli strain $\mathrm{T}_{100}$, were obtained from the National Institute of Cholera and Enteric Diseases, Calcutta, WHO Collaborating Centre for Diarrhoeal Diseases Research and Training. The bacteria were grown in tryptic soy broth for 18 hours in a shake culture. The growths were centrifuged for 30 minutes at $4000 \times g$. The supernatants were assayed for the presence of ST or LT enterotoxins. The bioactivity of ST enterotoxin containing supernatant was tested by suckling mouse assay. ${ }^{13}$ Briefly, the supernatant was diluted twofold serially and $0 \cdot 2 \mathrm{ml}$ of each dilution was given intragastrically to a batch of three mice. The last dilution giving a response greater than 0.09 (ratio of gut to remaining body weight) after four hours was considered as the end point and was expressed as the number of mouse units per $0.5 \mathrm{ml}$. After measuring the concentration, each animal was given intragastrically $0.5 \mathrm{ml}$ of toxin containing 32 mouse units. The animals were killed four hours after the treatment. The presence of ST toxin was also confirmed by enzyme linked immunosorbent assay (ELISA). ${ }^{14}$ Briefly, to each well of the ST enterotoxin coated plates, $50 \mu$ l of the supernatant was added. Immediately, $50 \mu$ l of antiserum was added to the toxin. After one hour of incubation at $37^{\circ} \mathrm{C}$, the plate was washed and $100 \mu \mathrm{l}$ of horseradish peroxidase conjugated antirabbit immunoglobulin was added. The plate was incubated for one hour at $37^{\circ} \mathrm{C}$ and washed with phosphate buffered saline. The substrate was added and colour read after 10 minutes. Inhibition of more than $50 \%$ of the negative control confirmed the presence of ST enterotoxin.

The presence of LT enterotoxin was confirmed by ELISA as described by Honda et al with some modifications. ${ }^{15}$ Briefly, the sample was diluted twofold serially and $50 \mu \mathrm{l}$ of each dilution was added to each well coated with anti heat-labile enterotoxin antibodies. The plate was washed three times with phosphate buffered saline. This was followed by the addition of $50 \mu l$ of anti heatlabile enterotoxin conjugated to horseradish \\ 17 February 1994 \\ Department \\ and Exper
}




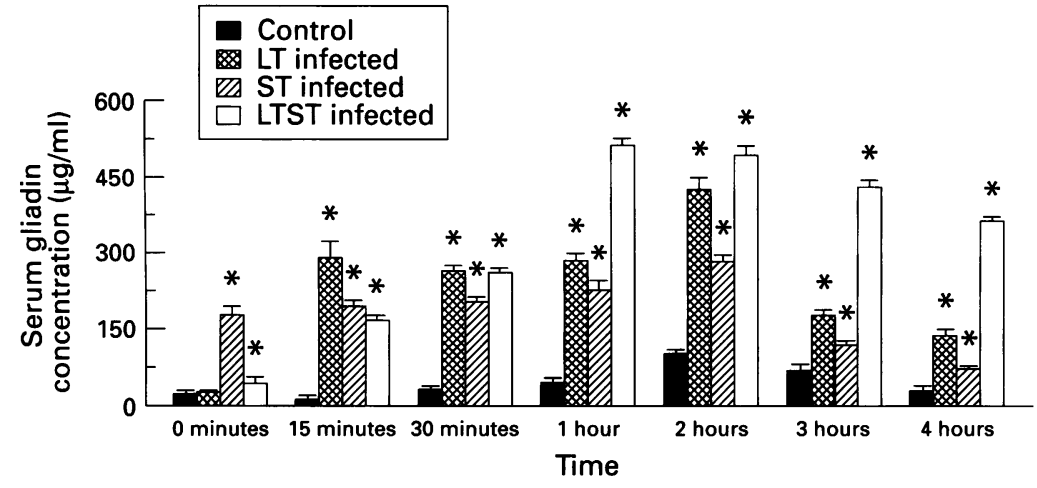

Figure 1: Effect of $\mathrm{E}$ coli enterotoxins on absorption of gliadin from mice intestine after four hours of infection. Values are expressed as mean (SEM) of six determinations; ${ }^{\star} p<0 \cdot 001$ compared with control at same time interval.

peroxidase. Finally, the substrate was added to each well, colour developed, and was read at $490 \mathrm{~nm}$ in ELISA reader. The amount of sample giving optical density of 1.0 was taken as 1.0 unit. Different animals were given $4,8,16$, 32 , and 64 units of LT enterotoxin of $E$ coli. Control mice received an equal volume of sterile broth. The activity of LT enterotoxin was determined by rabbit ileal loop assay. 16 Briefly, one $\mathrm{ml}$ supernatant containing LT enterotoxin was injected into a ligated loop (10 $\mathrm{cm})$. The rabbits were killed 18 hours after the challenge and volume to length ratios $(\mathrm{ml} / \mathrm{cm})$ were determined. A ratio of more than one was considered as positive. After working out the concentration each animal was given intragastrically 32 units of LT enterotoxin. The animals were killed four hours after the treatment.

\section{IMMUNISATION PROCEDURE}

Polyclonal antiserum samples were raised against crude gliadin (Sigma) and bovine $\alpha$ lactalbumin (Sigma) in New Zealand white rabbits weighing 2-3 kg according to the method of Friis. ${ }^{17} \mathrm{~A}$ gliadin solution of $1 \mathrm{mg} / \mathrm{ml}$ of $100 \mathrm{mM}$ lactic acid was prepared. The rabbits were injected intracutaneously every second week with $200 \mu l$ of solution added to an equal volume of Freund's incomplete adjuvant. The rabbits were bled one week after the sixth and the last injection. The whole schedule for raising antibodies against

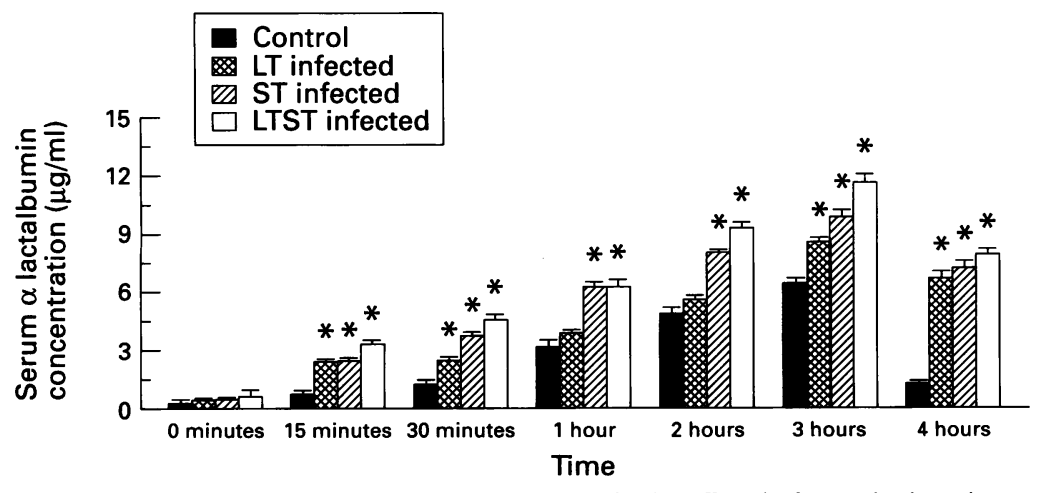

Figure 2: Effect of $\mathrm{E}$ coli enterotoxins on absorption of $\alpha$ lactalbumin from mice intestine after four hours of infection. Values are expressed as mean (SEM) of six determinations; ${ }^{\star} p<0.01$ compared with control at same time interval. $\alpha$ lactalbumin was the same as for gliadin except that the $\alpha$ lactalbumin solution was

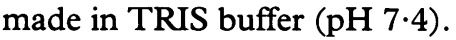

The visualisation of immunoreactive gliadin and $\alpha$ lactalbumin was carried out by ELISA and was compared with normal rabbit serum samples. Briefly, the microtitre plates were coated with $100 \mu \mathrm{l}$ of crude gliadin $(2-5 \mu \mathrm{g} / \mathrm{ml}$ $70 \%$ ethanol) or $\alpha$ lactalbumin $(1 \mu \mathrm{g} / \mathrm{ml}$ $10 \mathrm{mM}$ TRIS buffer, $\mathrm{pH} 7 \cdot 4$ ) and kept overnight at $4^{\circ} \mathrm{C}$. Plates were washed three times with phosphate buffered saline containing TWEEN-20 (PBST). To each well $200 \mu l$ of PBST containing $1 \%$ bovine serum albumin was added and incubated at $37^{\circ} \mathrm{C}$ for one hour. After washing three times with PBST, to each well $100 \mu l$ of the suitably diluted test serum samples (1:2000) were added and the plates were incubated for four hours at $37^{\circ} \mathrm{C}$. The plates were washed three times with PBST. One hundred $\mu$ l of horseradish peroxide conjugated antirabbit antigliadin or antilactalbumin antibody (1:2000 dilution) was added to each well and-kept overnight at $4^{\circ} \mathrm{C}$. Plates were again washed three times with PBST. To each well $100 \mu$ l of freshly prepared substrate was added and plates were incubated in the dark at $37^{\circ} \mathrm{C}$ for one hour. The reaction was stopped by an addition of $50 \mu \mathrm{l} /$ well of $6 \mathrm{~N} \mathrm{H}_{2} \mathrm{SO}_{4}$ and optical density was read at $492 \mathrm{~nm}$ by ELISA reader.

\section{MEASUREMENT OF MACROMOLECULAR ABSORPTION}

Crude gliadin and bovine $\alpha$ lactalbumin were fed by mouth with the help of a plastic feeding tube to control mice and mice infected with LT, ST, and both LT, ST toxins. In each group, there were 12 mice and serum samples of two mice were pooled resulting in six samples. Blood was drawn at different time intervals ranging from 0 minutes, 15 minutes, one hour, two hours, three hours, and four hours after ingestion of proteins. Serum samples were separated. Gliadin and $\alpha$ lactalbumin concentrations were determined by ELISA using the antibodies that were raised against gliadin and lactalbumin.

\section{Results}

Although the concentrations of these proteins started increasing significantly after 15 minutes of their ingestion, the peak values of gliadin and bovine $\alpha$ lactalbumin were found at two and three hours respectively in both control and experimental groups (Figs 1 and 2). There was also a significant increase $(p<0.001)$ in the absorption of gliadin at two hours in the experimental group compared with the control group (Fig 1). Similarly, there was a significant $(p<0.01)$ increase in the absorption of $\alpha$ lactalbumin at three hours in all experimental groups compared with the control group (Fig 2).

\section{Discussion}

An increased uptake of macromolecular 
protein antigen because of increased permeability has been reported in food allergic subjects. ${ }^{1819}$ Low concentrations of protein antigens have been detected in the serum of healthy subjects after ingestion of protein. ${ }^{18} 20$ In this study, the effect of diarrhoea caused by ETEC was seen on antigen absorption in weanling mice. Gliadin and lactalbumin were chosen for studying macromolecular absorption in the mouse model as these proteins are unrecognised by the mouse immune system and this avoids the problems of immune clearance through antigen-antibody complex formation.

Byars and Ferraresi ${ }^{21}$ suggested that in the rat maximal gut permeability occurred 45 minutes after inducing a local hypersensitivity reaction. In our study we found that the absorption of two macromolecules, gliadin and lactalbumin, achieved peak value at two and three hours respectively after ingestion in both experimental and control groups. There was a significant increase in the absorption of the two proteins in serum in infected groups compared with controls. The concentration of proteins in serum samples may result from several functions such as the proteolytic capacity of the gut, the transfer of the antigenic protein from the gut lumen to blood, and the clearance of the protein from blood. It has been reported that acute infection in animals is associated with altered mucosal and systemic immune responses and may promote sensitisation to the allergens present at the epithelium. ${ }^{22}$ There are similar reports for Lumans that show that epithelial alterations resulting from gastrointestinal diseases are responsible for increased passage of food antigens ${ }^{2324}$ and these may induce allergic reactions in certain subjects. ${ }^{2526}$ This is an indication that changes in intestinal permeability take place in certain disorders. Our results also show that changes in intestinal permeability in ST and LT induced diarrhoea are responsible for increased passage of gliadin and lactalbumin. Isolauri et $a l^{27}$ have shown that the small intestinal epithelium of rabbits is more permeable to intact proteins at weaning than later in life, which might result from the immaturity of the immune function or differences in the membrane composition. A similar phenomenon has also been shown in human studies. ${ }^{28}$ This may also be a reason for increased passage of proteins through small intestinal epithelium as we have used the weanling mouse model in our study and species specific differences in this phenomenon are also known to occur.

The rabbit specific $E$ coli strain RDEC-I infection also leads to a transient increase in the absorption of antigenic $\beta$ lactaglobulin and intact horseradish peroxidase during peak phase of diarrhoea in rabbits. ${ }^{27}$ This infection does not result in disruption of the epithelial layer. Similarly, ETEC producing ST and LT used in this study are not known to invade the enterocytes and yet have caused an increase in macromolecular absorption. The uptake of larger amounts of dietary antigens was also seen in children recovering from acute diarrhoea. ${ }^{23}$ The possible influence of infectious diarrhoea on the sensitisation in infants is still under investigation. Acute infections have been shown to cause physiological disturbances and structural modifications of the small intestinal mucosa, which may interfere with the exclusion of foreign protein by the mucosal barrier. ${ }^{12}$ The increase in antigenic absorption seen in this study during the acute phase of infection may be paracellular or transcellular resulting from disturbances of the cytoskeletal network as shown in cultured human intestinal epithelial monolayers ${ }^{29}$ or resulting from changes in brush border membrane composition or fluidity, or both or because of a change in the rate limiting component or change in the barrier in the macromolecular movement. The data reported concerning changes in mucosal handling during acute gastroenteritis are scanty, however, and still controversial. This is probably because of differences between experimental conditions and the causes of the various types of diarrhoeas.

1 Kelijo DJ, Butter DG, Hamilton JR. Altered jejunal permeability during viral enteritis in the piglet. Gastroenterology 1985; 88: 998-1004.

2 Heyman M, Corthier G, Petit A, Mestin JC, Morean C, Desjeux JF. Intestinal absorption of macromolecules during viral enteritis: an experimental study on rotavirus infected conventional and germ free mice. Pediatr Res 1987; 22: 72-8.

3 Gotteland M, Isolauri E, Heyman M, Tome D, Desjeux JF. Antigen absorption in bacterial diarrhoea: in vivo intestinal transport of beta-lactoglobulin in rabbits infected with the enteroadherent E coli strain RDEC-I. Pediatr Res 1989; 26: 237-40.

4 Heyman $M$, Dumontier AM, Desjeaux JF. Intestinal barrier to intact horseradish peroxidase in experimental secretory diarrhoea. 7 Pediatr Gastroenterol Nutr 1986; 5: 463-6.

5 Walker WA. Intestinal transport of macromolecules. In: Johnson LR, ed. Physiology of the gastrointestinal tract. New York: Raven Press, 1981: 1271-89.

6 Ryder RD, Wachsmuth IK, Buxton AE, Evans DG, Dupont $\mathrm{HL}$, Mason E, et al. Infantile diarrhoea produced by heatstable enterotoxin of $\mathrm{E}$ coli. $N$ Engl $\Im$ Med 1976; 295: 849-53.

7 Gianella RA. Pathogenesis of acute bacterial diarrhoeal disorders. Annu Rev Med 1981; 32: 341-57.

8 Smith HW, Gyles CL. The relationship between two apparently different enterotoxins produced by enteropathogenic strains of E coli of porcine origin. F Med Microbial 1970; 3: 387-401.

9 Sack RB, Hirschhorn N, Brownlee I, Cash RA, Woodward WA, Sack DA. Enterotoxigenic E coli associated diarrhoeal diseases in Apache children. N Engl f Med 1975; 292: 1041-5.

10 Evans DJ, Chen LC, Curlin GT, Evans DG. The stimulation of adenyl cyclase by heat-labile enterotoxin. Nature 1972; 236: 137-8.

11 Staples SJ, Asher SE, Giannella RA. Purification and characterization of heat-stable enterotoxin produced by a strain of E coli pathogenic for man. F Biol Chem 1980; 255: 4716-21.

12 Goyal J, Ganguly NK, Mahajan RC, Garg UC, Walia BNS. Studies on the mechanism of $\mathrm{E}$ coli heat-stable enterotoxin induced diarrhoea in mice. Biochem Biophys Acta 1987; 925: 341-8.

13 Giannella RA. Suckling mouse model for detection of heatstable E coli enterotoxin. Characteristics of the model. Infant Immun 1976; 14: 95-9.

14 Mol PD, Hemelhof W, Retore P, Takeda T, Miwatani T, Takeda $\mathrm{Y}$, et al. A competitive immunosorbent assay for Takeda Y, et al. A competitive immunosorbent assay for Microbiol 1985; 20: 69-74.

15 Honda T, Sato M, Miwatani T. Differential detection of cholera enterotoxin and $\mathrm{E}$ coli heat-labile enterotoxin by enzyme-linked immunosorbent assay with antibodies specific to the two toxins. $\mathcal{F}$ Clin Microbiol 1984; 20: 664-7.

16 Evans DG, Evans DJ Jr, Pierce NF. Differences in the response of rabbit small intestine to heat-labile and heatstable enterotoxins of $\mathrm{E}$ coli. Infect Immun 1973; 7: 873-80.

17 Friis SU. Enzyme-linked immunosorbent assay for quantitation of cereal proteins toxic in coeliac disease. Clin Chim Acta 1988; 178: 261-70.

18 Paganelli R, Levinsky RJ, Atherton DJ. Detection of specific antigen within circulating immune complexes: validation of the assay and its application to formplexes: validation of the assay and its application to food antigen-antibody Clin Exp Immunol in healthy and 
19 Dannaeus A, Inganas $M$, Johansson SGO, Foucard $T$. Intestinal uptake of ovalbumin in malabsorption and food allergy in relation to serum IgG antibody and orally administered sodium cromoglycate. Clin Allergy 1979; 1: 263-70.

20 Husby S, Jensenius JC, Svehag SE. Passage of undegraded dietary antigens into the blood of healthy adults. Scand $\mathcal{f}$ Immunol 1985; 22: 83-92.

21 Byars NE, Ferraresi RW. Intestinal anaphylaxis in the rat as a model of food allergy. Clin Exp Immunol 1976; 24 352-6.

22 Leibovitz F, Freihorst J, Piedra PA, Ogra PL. Modulation of systemic and mucosal immune responses to inhaled
ragweed antigen in experimentally induced infection with ragweed antigen in experimentally induced infection with
respiratory syncytial virus implication in virally induced respiratory syncytial virus implication in virally induced

allergy. Int Arch Allergy Appl Immunol 1988; 86: 112-6. unaltered protein in normal infants and in infants recovering from diarrhoea. Pediatrics 1955; 16: 763-9.

24 Husby S, Foged N, Host A, Svehag SE. Passage of dietary antigens into the blood of children with coeliac disease. Quantification and size distribution of absorbed antigens Gut 1987; 28: 1062-72.

25 Walker WA. Absorption of proteins and protein fragments in developing intestine: the role of immunologic allergic reactions. Pediatrics 1985; 75: 167-71.

26 Strobel S. Developmental aspects of food allergy. In: Food allergy. Nestlé nutrition workshop series, Vol 17 Nestle Ltd, Vevey, New York: Raven Press, 1988: 99-117.

27 Isolauri E, Gotterland $M$, Heyman M, Pochart P, Desjeaux JF. Antigen absorption in rabbit bacterial diarrhoea (RDEC-I). Dig Dis Sci 1990; 35: 360-6.

28 Jackobsson I, Lindberg T, Lothe L, Axelsson I, Benediktsson B. Human alpha-lactabumin as a marker of macromolecular absorption. Gut 1986; 27: 1029-34.

29 Hecht G, Pothoulakis C, La Mont JT, Madara JL. Clostridium difficile toxin A perturbs cytoskeletal structure and tight junction permeability of cultured human intestinal epithelial monolayers. $\mathcal{F}$ Clin Invest 1988; 82: $660-9$. 